\title{
HYBRID WEAKNESS FOUND IN THE BACKCROSS PROGENY OF AN INTER-SPECIFIC CROSS OF ORYZA SATIVA / O. GLUMAEPATULA
}

\author{
Sobrizal $^{1 *}$, A. Yoshimura ${ }^{2}$ \\ ${ }^{1}$ Center for the Application of Isotopes and Radiation Technology, \\ National Nuclear Energy Agency (BATAN) \\ J1. Lebak Bulus Raya, P.O.Box 7002 JKSL, Jakarta 12070, Indonesia. Tel. 021-7690709, \\ Fax.021-7691607, e-mail sobrizal@lycos.com \\ ${ }^{2}$ Faculty of Agriculture Kyushu University, Hakozaki, Fukuoka, Japan.
}

Received 20 November 2008; Received in revised form 15 May 2009; Accepted 16 May 2009

\begin{abstract}
HYBRID WEAKNESS FOUND IN THE BACKCROSS PROGENY OF AN INTER-SPECIFIC CROSS OF ORYZA SATIVA / O. GLUMAEPATULA. Hybrid breakdown expressed as sterility or weakness or both in $\mathrm{F}_{2}$ or later generations is considered to be a reproductive barrier between two distantly related taxa. Hybrid breakdown that showed poor growth habit with fertile seeds was found in the backcross progenies $\left(\mathrm{BC}_{4} \mathrm{~F}_{2}\right)$ which were derived from a cross between a cultivated rice Oryza sativa L. cv. Taichung 65 and a wild rice Oryza glumaepatula Steud (Acc. IRGC 105668) where Taichung 65 was used as a recurrent parent. Through segregation analysis of $\mathrm{BC}_{4} \mathrm{~F}_{2}$ population, a novel gene for weakness was identified, and this gene was designated as $h w f 1$ (hybrid weakness f-1). RFLP (Restriction Fragment Length Polymorphism) analysis was employed to determine the chromosomal location of $h w f 1$ gene. The result revealed that $h w f 1$ was located between $G 3006$ and $C 933$ RFLP markers, with map distances of $0.5 \mathrm{cM}$ and $1.9 \mathrm{cM}$, respectively, and co-segregated with C708, C820, and R288 on the short arm of chromosome 4. Since both O. glumaepatula (Acc. IRGC 105668) and Taichung 65 that was used as parents showed normal growth habit, the weakness in this study was assumed to be controlled by a set of complementary recessive genes. One of the complementary genes is $h w f 1$ from O. glumaepatula, and another gene should be from Taichung 65 , because the genetic background of the $\mathrm{BC}_{4} \mathrm{~F}_{2}$ populations that were used for analysis is Taichung 65 . The gene from Taichung 65 has not been identified yet, therefore, it is necessary to conduct the experiment for finding out the complement of $h w f 1$ gene in near future.
\end{abstract}

Keywords: hybrid weakness, inter- specific cross, genetic map, rice

(C) 2009 Atom Indonesia. All rights reserved.

\section{INTRODUCTION}

In animals and plants, hybridization between two distantly related taxa frequently shows various forms of reproductive barriers such as hybrid sterility, hybrid weakness, and certation. These barriers promote development and also maintain the identity of species in nature however they also inhibit breeding efforts especially in introducing genes through wide crosses.

\footnotetext{
* Corresponding author.

E-mail addresses: sobrizal@batan.go.id, sobrizal@lycos.com (Sobrizal)
} 
These phenomena were classified into three types; hybrid in-viability (or weakness), hybrid sterility, and hybrid breakdown in the $\mathrm{F}_{2}$ or later generations [1]. Hybrid breakdown is expressed as either sterility or weakness or both.

Those three types of reproductive barriers have also been widely observed in the progenies of distantly related crosses of rice cultivars. Hybrid in-viability (or weakness) and hybrid sterility have been observed in inter- specific as well as in intra-specific crosses $[2,3,4,5,6,7,8,9,10]$, while hybrid breakdown has been reported only in intra-specific crosses $[2,11,12,13,14]$. By using molecular linkage maps, some of the genes controlling reproductive barriers have been located on several chromosomes $[8,9,10,12,13,15]$.

In a previous study [16], a series of Oryza glumaepatula (IRGC 105668) introgression lines with $O$. sativa cv. Taichung 65 genetic back-ground was developed by backcrossing and marker assisted selection methods. In the process of development of the introgression lines, it was observed that the hybrid breakdown expressed as weakness segregated in $\mathrm{BC}_{4} \mathrm{~F}_{2}$ population. The objectives of this study were to identify the gene responsible for weakness and to map the identified gene on RFLP (Restriction Fragment Length Polymorphism) linkage map.

\section{MATERIALS AND METHODS}

\section{Plant Materials}

A cultivated rice Oryza sativa L. cv. Taichung 65 and a wild rice $O$. glumaepatula Steud (Acc. IRGC 105668) were used as original crosses in constructing of $O$. glumaepatula introgression lines. The resultant $\mathrm{F}_{1}$ plants served as female parents were continuously backcrosses with Taichung 65 to generate $\mathrm{BC}_{4} \mathrm{~F}_{1}$ populations. Molecular selection in the construction of introgression lines was described in previous report [14]. The RFLP genotypes of $\mathrm{BC}_{4} \mathrm{~F}_{1}$ in previous study were used as reference data in this study. One of the $\mathrm{BC}_{4} \mathrm{~F}_{2}$ populations segregated for weak plants was used as mapping population as well as in genetic analysis.

\section{DNA Extraction and RFLP Analysis}

DNA was extracted from frozen leaf samples using the CTAB (Cetyltrimethyl ammonium bromide) method [17]. The isolated DNA $(2.5 \mu \mathrm{g}$ ) was digested with restriction enzymes (Apa I, BamH I, Bgl II, Dra I, EcoR I, EcoR V, Hind III, Kpn I). DNA markers were used DNA clones that have mapped previously by HARUSHIMA, et al. [18].

In this study, almost all the probes were labeled with HRP (horseradish peroxidase). The procedure of labeling and detection with HRP followed the 
protocol of ECL direct nucleic acid labeling and detection system recommended by kit producer (Amersham Company). For this purpose, digested DNA was separated by $0.8 \%$ agarose-gel electrophoresis and blotted onto Hybond- $\mathrm{N}^{+}$nylon membranes by capillary transfer on $0.4 \mathrm{~N} \mathrm{NaOH}$ for 12 hours. The blotted membranes were rinsed in $2 \mathrm{X} \mathrm{SSC}$, dried and baked at $120^{\circ} \mathrm{C}$ for 20 minutes. Hybridized membranes were detected by enhanced chemiluminescence on Fuji X-ray film for 1-3 hours.

The probes which showed unclear bands were labeled with alpha

${ }^{32} \mathrm{P}$-dCTP by the random hexamer method [19] using a multiprime DNA labeling system. For this purpose, digested DNA was separated by $0.8 \%$ agarose-gel electrophoresis and blotted onto Hybond-N nylon membranes by capillary transfer in $20 \mathrm{X} \mathrm{SSC}$. After blotting overnight, the membranes were rinsed in $2 \mathrm{X} \mathrm{SSC}$, dried, and baked at $80^{\circ} \mathrm{C}$ for 2 hours. The labeled probes were individually hybridized overnight at $42^{\circ} \mathrm{C}$ in a hybridization solution (4 X SSPE, $10 \%$ blotto, $50 \%$ formamide, $10 \%$ SDS, $0.5 \mathrm{mg} / \mathrm{ml}$ salmon DNA) and washed twice at $42^{\circ} \mathrm{C}$ for 30 minutes each with $6 \mathrm{X}$ SSC containing $0.2 \%$ SDS. After washing, the membranes were exposed to Kodak X-Omat AR film for $3-10$ days at $-80^{\circ} \mathrm{C}$ with an intensifying screen.

\section{Data Analysis}

The $\chi^{2}$ test was performed to examine fitness of the weak plant frequencies against expectation from Mendelian segregation. Recombination values were estimated with the maximum likelihood equation [20]. Obtained values were converted into map distances ( $\mathrm{cM}=$ centi Morgan) using the Kosambi function [21].

\section{RESULTS AND DISCUSSION}

During development process of $O$. glumaepatula introgression lines with $O$. sativa genetic background, it was observed that the weak plants segregated in $\mathrm{BC}_{4} \mathrm{~F}_{2}$ population. A weak plant was characterized by small number of tillers, short culms and panicles with fertile seeds (Figure 1). The weak plants were found in $\mathrm{BC}_{4} \mathrm{~F}_{2}$ populations with O. glumaepatula cytoplasm as well as in $\mathrm{BC}_{4} \mathrm{~F}_{2}$ populations with Taichung 65 cytoplasm, suggesting that the weakness was not due to a cytoplasmic effect. Moreover, the parents $\left(\mathrm{BC}_{4} \mathrm{~F}_{1}\right.$ plants $)$ of the segregating populations showed normal growth habits. Therefore, this weakness was proposed to be a hybrid breakdown. 


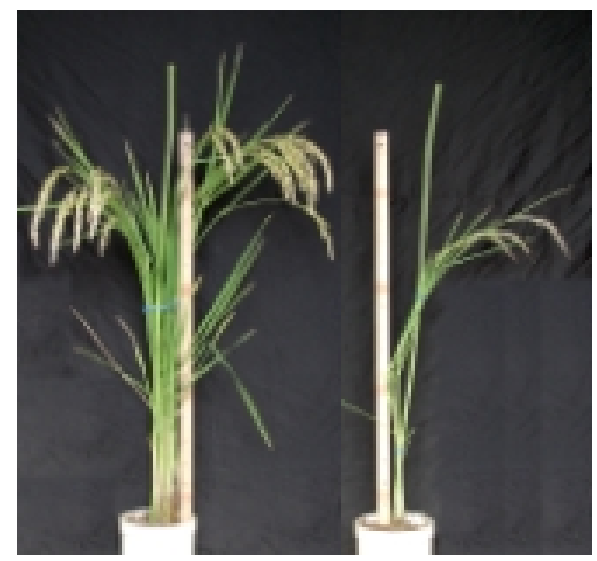

Figure 1. Phenotype of normal plant (left) and weak (right) segregated in $\mathrm{BC}_{4} \mathrm{~F}_{2}$ population.

In rice, hybrid breakdown expressed as weakness in the $F_{2}$ or later generation, firstly reported by OKA [2] through observation of the progenies that was derived from crossing of some Asian varieties. This weakness was caused by complementary recessive genes, but the chromosomal locations of these genes were not known yet. The same phenomenon was also reported by OKUNO [11], KUBO and YOSHIMURA [12]. OKUNO [11] found the weakness in the $F_{2}$ or later generations in the progenies of a cross of Thai glutinous variety (Col.15) and Japanese variety, Sasanisiki. He explained that this weakness was caused by a set of recessive genes of $h w d l$ and $h w d 2$. These $h w d l$ and $h w d 2$ genes were located on chromosome 10 and chromosome 7, respectively [15]. KUBO and YOSHIMURA [12] found the weakness in the $\mathrm{F}_{2}$ or later generations in the progenies of a cross of Indica rice, IR24, and Japonica rice, Asominori. A set of complementary recessive genes of hwel and hwe 2 that was located on chromosome 12 and chromosome 1, respectively was responsible for this weakness.

The $\mathrm{BC}_{4} \mathrm{~F}_{2}$ population that was used in this study segregated into 86 normal and 20 weak plants (Table 1). The segregation pattern in $\mathrm{BC}_{4} \mathrm{~F}_{2}$ population was confirmed by a progeny test using $\mathrm{BC}_{4} \mathrm{~F}_{3}$ lines. The result showed 36 lines fixed for normal, 50 lines segregated, and 20 lines fixed for weakness (Table 1). These ratios fitted the $3: 1\left(\chi^{2}=2.1 ; \mathrm{p}=0.015\right)$ and 1:2:1 $\left(\chi^{2}=5.2 ; \mathrm{p}=0.07\right)$ in $\mathrm{BC}_{4} \mathrm{~F}_{2}$ and $\mathrm{BC}_{4} \mathrm{~F}_{3}$, respectively, indicating that weakness in this population was controlled by a single recessive gene. 
Table 1. Segregation of normal and weak plants in $\mathrm{BC}_{4} \mathrm{~F}_{2}$ population and in $\mathrm{BC}_{4} \mathrm{~F}_{3}$ lines

\begin{tabular}{|c|c|c|c|c|c|}
\hline Population /lines & Normal & Segregating & Weak & Total & $\chi^{2}$ \\
\hline $\mathrm{BC}_{4} \mathrm{~F}_{2}$ & 86 & - & 20 & 106 & $2.1^{\mathrm{ns})}(3: 1)$ \\
\hline $\mathrm{BC}_{4} \mathrm{~F}_{3}$ & 36 & 50 & 20 & 106 & $5.2^{\text {ns) }}(1: 2: 1)$ \\
\hline
\end{tabular}

${ }^{\mathrm{Ns})}$ non significant

RFLP analysis was conducted using $\mathrm{BC}_{4} \mathrm{~F}_{2}$ population in order to determine the chromosomal location of the gene that controls this weakness. Based on whole genome survey of candidate $O$. glumaepatula introgression lines, the $\mathrm{BC}_{4} \mathrm{~F}_{2}$ population used in this study has retained O. glumaepatula chromosomal segment on chromosome 4 and 6 [16]. Several RFLP markers located on chromosome 4 and 6 were used in linkage analysis. The results revealed that the gene for weakness was located between G3006 and C933, with map distances of $0.5 \mathrm{cM}$ and $1.9 \mathrm{cM}$, respectively, and co-segregated with C708, C820, and R288 RFLP markers on the short arm of chromosome 4 (Figure 2, Table 2). Nineteen plants with weak phenotype were homozygous for $O$. glumaepatula allele, 36 plants with normal phenotype were homozygous for Taichung 65 alllele, and the others 48 plants with segregating phenotype were heterozygous. These results confirmed that the weakness in this segregating population was controlled by a single recessive gene, and this gene was closed to R1607.

Even though five complementary gene sets for weakness, $H w a, h w b$, $h w c, h w d$, and $h w e$, have been stated [2, 4, 12, 15], there was no reported gene on chromosome 4. Therefore, the gene identified in this study was considered as a novel gene and designated as hwfl (hybrid weakness f-1) following the report on hwel [12].

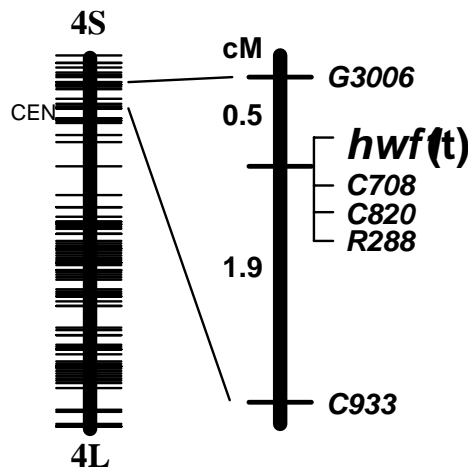


Figure 2. Linkage map of chromosome 4 showing the location of $h w f 1$. Framework map on the left is quoted from HARUSHIMA, et al. [16].

In this study, both $O$. glumaepatula (Acc. IRGC 105668) and Taichung 65 used as parents showed normal growth habit. Therefore, the weakness in this study was considered to be controlled by a set of complementary recessive genes. One of the complementary genes is $h w f l$ from $O$. glumaepatula. Supposed another gene is $a$. The gene $a$ should be from Taichung 65 , because the genetic background of the $\mathrm{BC}_{4} \mathrm{~F}_{2}$ populations that was used for analysis is Taichung 65. Genotypes of O. glumaepatula and Taichung 65 would be hwflhwfl $A A$ and HwflHwfl $a a$, respectively. The segregants with double recessive genes, such as hwflhwfl aa would express weakness, whereas those with the remaining genotypes would grow normally. The gene from Taichung 65 has not been identified yet.

Table 2. Relationship between weak and genotype at RFLP marker C708 in $\mathrm{BC}_{4} \mathrm{~F}_{3}$ lines.

\begin{tabular}{|l|c|c|c|}
\hline \multirow{2}{*}{ Phenotype } & \multicolumn{3}{|c|}{ Genotype at C708 } \\
\cline { 2 - 4 } & $\left.\mathrm{TT}^{*}\right)$ & $\mathrm{TG}^{*}$ & $\left.\mathrm{GG}^{*}\right)$ \\
\hline Normal & 36 & 0 & 0 \\
\hline Segregating & 0 & 48 & 0 \\
\hline Weak & 0 & 0 & 19 \\
\hline
\end{tabular}

') TT, TG, GG are Taichung 65 homozygous, heterozygous, and $O$. glumaepatula homozygous alleles, respectively

The previous reports concerning hybrid breakdown only involved on the progenies of intra-specific crosses [2, 12,15]. Geographic distributions of hybrid breakdown controlled by $h w d l$ and $h w d 2$ genes have been surveyed in rice varieties [15]. The result suggested that hybrid breakdown controlled by this genic system would not effect rice varietal differentiation. On the other hand, when SATO and HAYASHI [5] surveyed the geographical distribution of complementary genes that caused $\mathrm{F}_{1}$ weakness and the result suggested that the possession of $L-2-a$ gene may be considered as a characteristic of the temperate Japonica type of rice. In our study, weakness was found in the progenies of a cross of $O$. sativa and $O$. glumaepatula. It is the first report on hybrid breakdown found in inter-specific cross. Investigating the allelic distribution in $O$. sativa and in wild relatives would allow a better understanding of the process of rice speciation, and serve as a useful criterion for the selection of parental varieties in cross breeding programs. 


\section{CONCLUSIONS} as follow:

Based on the results of this study, some conclusions were summarized

1. A novel gene for hybrid weakness was identified using Oryza glumaepatula introgression lines.

2. The gene was designated as $h w f l$, and mapped between $G 3006$ and $C 933$ RFLP markers, with map distances of $0.5 \mathrm{cM}$ and $1.9 \mathrm{cM}$, respectively, and co-segregated with C708, C820, and R288 RFLP markers on the short arm of chromosome 4.

\section{ACKNOWLEDGMENT}

We thank Ms. C. Tanaka for technical assistance. This study was supported in part by Bio-oriented Technology Research Advancement Institution (BRAIN), Japan.

\section{REFERENCES}

1. STEBBINS, G. L., "Isolation and the origin of the species". In: STEBBINS, Jr. G. L. (ed). Variation and Evaluation in Plants, Columbia Univ. Press, New York, 189-250 (1950).

2. OKA, H. I., Jpn. J. Genet. 32:83-87 (1957).

3. OKA, H. I., Genetics, 77, 521-534 (1974).

4. AMEMIYA, A. AKEMINE, H., Bull. Natl. Inst. Agric. Sci. Ser. D10, 139-226 (1963).

5. SATO, Y. I., HAYASHI, K., Jpn. J. Genet, 58, 411-418 (1983).

6. IKEHASHI, H., ARAKI, H., "Genetics of $F_{1}$ sterility in remote crosses of rice. In: KHUSH, G.S. (ed). Rice Genetics", International Rice Research Institute. Manila, 119-130 (1986).

7. SANO, Y., Heredity, 74, 435-439 (1983).

8. DOI, K., TAGUCHI, K., YOSHIMURA, A., Rice Genet. Newsl., 16, 65-68 (1999).

9. SOBRIZAL, MATSUZAKI, Y., IKEDA, K., SANCHEZ, P. L., DOI, K., YASUI, H., ANGELES, E. R., KHUSH, G. S., YOSHIMURA, A., "Oryza glumaepatula Steud. Introgression lines in rice: identification of the genes for reproductive barriers". In: KHUSH, G. S., BRAR, D. S., 
HARDY, B. (ed). Advancas in Rice Genetics. International Rice Research Institute. Los Banos, Philippines, 128-130 (2003).

10. ICITANI, K., NAMIGOSHI, K. SATO, M., TAURA, S., AOKI, M., MATSUMOTO, Y., SAITO, T., MARUBASHI, W., KUBOYAMA, T., Theor. Appl. Genet., 134, 1407-1415 (2007).

11. OKUNO, K., Rice Genet. Newsl., 2, 52-54 (1985).

12. KUBO, T., YOSHIMURA, A., Theor. Appl. Genet., 105, 906-911 (2002).

13. KUBO, T., YOSHIMURA, A., Theor. Appl. Genet., 110, 346-355 (2005).

14. FUKUOKA, S., NEWINGHAM, M. C. V., ISHTIAQ, M., NAGAMINE, T., KAWASE, M., OKUNO, K., Rice Genet. Newsl., 22, 29-31 (2005).

15. FUKUOKA, S., NAMAI, H., OKUNO, K., Theor. Appl. Genet., 97, 446-449 (1998).

16. SOBRIZAL, IKEDA, K., SANCHEZ, P. L., DOI, K., ANGELES, E. R., KHUSH, G. S., YOSHIMURA, A., Rice Genet. Newsl., 16, 107-108 (1999).

17. MURRAY, M., THOMPSON, W.F., Nucleic Acid Res., 8, 4321-4325 (1980).

18. HARUSHIMA, Y., YANO, M., SHOMURA, A., SATO, M., SHIMANO, T., KUBOKI, Y., YAMAMOTO, T., LIN, S. Y., ANTONIO, B. A., PARCO, A., KAJIYA, H., HUANG, N., YAMAMOTO, K., NAGAMURA, Y., KURATA, N., KHUSH, G. S., and SASAKI, T., Genetics, 148: 479-494 (1998).

19. FEINBERG, A. P. and VOLGELSTEIN, B., Anal. Biochem., 132, 6-13 (1983).

20. ALLARD, R.W., Hilgardia, 24, 235-278 (1956).

21. KOSAMBI, D., Ann. Eugen., 12, 172-175 (1944). 